\title{
Orthodox Clubs and Associations: Cultural, Educational and Religious Networks Between Palestine and Transjordan, 1925-1950
}

\author{
Norig Neveu
}

The aftermath of the First World War and the fall of the Ottoman Empire saw the creation of new states under mandates of the League of Nation. From 1920, Palestine and then Transjordan were placed under British Mandate. Meanwhile, new political ideals prevailed among local political representatives, including Arab nationalism. In 1922, Abdallah, son of Sharif Husayn of Mecca, one of the leaders of the Arab Revolt, and a strong supporter of the Arab nationalist project was appointed Emir of Transjordan. ${ }^{1}$ The formation by Emir Abdullah of a Transjordanian government mainly composed of officials from Syria, Palestine and the Hijaz led to some hostility towards him from local notables, but the Emir quickly established his power based on the growing allegiance of some of the regional tribes. ${ }^{2}$ On their side, British officials had two imperatives: ensuring the creation of a Transjordanian national sentiment without attracting the mistrust of the Transjordanian tribes. To do so, British representatives encouraged a social and political confessionalisation

\footnotetext{
${ }^{1}$ M. C. Wilson, "The Hashemite, the Arab Revolt, and Arab Nationalism," in The Origins of Arab Nationalism, eds. K. Rashid, Lisa Anderson, Muhammad Muslih, and Reeva S. Simon (New York: Columbia University Press, 1991), 204-224.

${ }^{2}$ M. C. Wilson, King Abdullah, Britain and the Making of Jordan (Cambridge: Cambridge University Press, 1990).
}

N. Neveu $(\bowtie)$

French National Centre for Scientific Research, Aix-Marseille University, Aix-en-Provence, France

e-mail: norig.NEVEU@univ-amu.fr

(C) The Author(s) 2021

K. Sanchez Summerer and S. Zananiri (eds.), European Cultural

Diplomacy and Arab Christians in Palestine, 1918-1948,

https://doi.org/10.1007/978-3-030-55540-5_3 
and established legal frameworks attributing a minority status to Christians. ${ }^{3}$ They also supported the development of British and American Protestant missions. ${ }^{4}$ At the same time, the Greek Orthodox Church was experiencing an intense financial crisis. For all these reasons, the interwar period appeared to Orthodox Arab notables as a pivotal period to establish local authority in Amman and Transjordan through the work of associations and their ties with the Orthodox laity in Palestine.

The Christian, Catholic and Protestant missionary movement had experienced a revival in the nineteenth century, ${ }^{5}$ a trend which played an important role in Middle Eastern societies, leading to the creation of schools, universities and hospitals. These institutions became the structures around which intellectual life and state administrations of the Ottoman Empire revolved. ${ }^{6}$ Yet it is most often from the perspective of the cultural diplomacy of the states to which these missions were attached, mainly France and Great Britain, that these missions have been viewed, without necessarily measuring their social impact in the Middle East. ${ }^{7}$ Most missionaries had to leave the Middle East or at least their missions during the First World War ${ }^{8}$ and the missionary strategies of the Churches thus changed during the interwar period, encouraging the role of Arab priests and teachers. ${ }^{9}$

In the aftermath of World War I, the intellectual life of the nabda ${ }^{10}$ was very vivid, especially in Palestine, with important Arabic literature production, journalistic activity and the development of cultural societies in the

${ }^{3}$ G. Chatelard, Briser la mosä̈que. Les tribus chrétiennes de Madaba, Jordanie (XIX-XXe siècle) (Paris: CNRS Editions, 2004).

${ }^{4}$ L. Robson, Colonialism and Christianity in Palestine (Austin: University of Texas Press, 2011).

${ }^{5}$ U. Makdisi, Artillery of Heaven: American Missionaries and the Failed Conversion of the Middle East (London: Cornell University Press, 2008); C. Verdeil, La mission jésuite du MontLiban et de Syrie (1830-1864) (Paris: Les Indes Savantes, 2011); H. J. Sharkey, Cultural Conversions: Unexpected Consequences of Christian Missions in the Middle East, Africa, and South Asia (Syracuse: Syracuse University Press, 2013).

${ }^{6} \mathrm{P}$. Bourmaud, "Discipline et familiarisation à travers la médecine: une mission médicale à Gaza (1878-1914)," Missions religieuses, missions médicales et “mission civilisatrice” (XIXe et XXe), Histoire, monde et cultures religienses 1, no. 21 (2012): 81-102; C. Verdeil, ed., Missions chrétiennes en terre d'islam ( $\mathrm{XVII}^{e}-\mathrm{xx}^{e}$ siècles). Anthologie de textes missionnaires (Turnhout: Brepols, 2013).

${ }^{7}$ J. Bocquet, Missionnaires français en terre d'islam, Damas 1860-1914 (Paris: Les Indes Savantes, 2005).

${ }^{8}$ R. Mazza, "Churches at War: The Impact of the First World War on the Christian Institution of Jerusalem, 1914-1920," Middle Eastern Studies 45, no. 2 (2009): 207-227.

${ }^{9} \mathrm{~N}$. Neveu, "Between Uniatism and Arabism: Missionary Policies and Diplomatic Interest of the Melkites in Jordan During the Interwar Period," Social Sciences and Mission, Special Issue: Missions, Powers and Arabization vol. 32, nos. 3-4 (2019): 361-392.

${ }^{10}$ L. Dakhli, Une génération d'intellectuels arabes. Syrie et Liban (1908-1940) (Paris: Karthala, 2009); L. Kozma, A. Schayegh, and A. Wishnitzer, A Global Middle East: Mobility, Materiality and Culture in the Modern Age, 1880-1940 (London: I.B. Tauris, 2015). 
main cities. This cultural nationalism ${ }^{11}$ was embodied by intellectuals some of whom were also very involved in the Orthodox laity movement. Movement intellectuals such as Ḥanā and 'Isā al-'Isā played a structuring role from the formative context of the late nineteenth century Palestine and Transjordan. ${ }^{12}$ Through the Orthodox laity networks, these intellectuals were closely connected to their counterparts living in the Emirate of Transjordan.

This article approaches cultural diplomacy "from below", separate from state actions, ${ }^{13}$ through the initiatives of the Orthodox clubs and laity from 1925 to 1970 in the Emirate of Transjordan (later the Kingdom of Jordan). Cultural diplomacy is commonly considered to be the exportation of elements considered as representative of a national culture but also as interactions with other countries in the cultural field. ${ }^{14}$ This article argues that in a context of the defence of Arab nationalism in a state under Mandate authority, the Orthodox laity played a pivotal role in promoting cultural, intellectual and political production and narratives. Cultural diplomacy will thus be approached at a regional level, through the circulation of people, funding and models and as a way to negotiate local sovereignty and political space, away from the influence of the Patriarchate of Jerusalem.

Based on archival documents from British Mandate archives and interviews with current representatives of the Arab Orthodox associations in Transjordan ${ }^{15}$ this paper proposes a connected history of the Orthodox associations in Transjordan and Palestine during the Mandate and after the settlement of Palestinian refugees in Transjordan. Recent research shows the crucial importance of charities and associations within civil society in the Middle East. ${ }^{16}$ In this respect, this paper considers the history of the Orthodox associations with regard to the question of how deeply social dynamics in Transjordan were intertwined with regional dynamics. What circulation and

${ }^{11}$ A. Abu-Ghazaleh, "Arab Cultural Nationalism in Palestine During the British Mandate," Journal of Palestine Studies 1, no. 3 (1972): 37-63.

${ }^{12} \mathrm{~N}$. Tadros Khalaf, Les Mémoires de 'Issa al-'Issa. Journaliste et intellectuel palestinien (18781950) (Paris: Karthala, 2009).

${ }^{13} \mathrm{~J} .-\mathrm{M}$. Tobelem, L'arme de la culture - Les stratégies de la diplomatie culturelle non gouvernementale (Paris: L'Harmattan, 2007).

${ }^{14}$ P. M. Goff, "Cultural Diplomacy," in The Oxford Handbook of Modern Diplomacy, eds. A. F. Cooper, J. Heine, and R. Thakur (Oxford: Oxford University Press, 2013), 419-435.

${ }^{15}$ Due to the difficult access to the archives of the Greek Orthodox Patriarchate and a lack of centralisation of the archives of Arab Orthodox associations in Jordan, I use in this article archival documents from Arab Orthodox associations which were published in Raouf Abu Jaber's two-volume book and on the history of Orthodox associations from 1875 to 2015 in Jordan, R. S. Abujaber, Al-Nabda al-urthûduksiyya fi al-Raja' al-Batriarkia al-Maqdissiyya, 1865-2015, Vol. 1-2 (Amman: National Press, 2016). I also use documents published in the annexes to the Memoirs of 'Awda al-Qusūs edited by his descendants. From the 1950s, the associations published also many brochures and documentation for internal purpose. They represent precious sources for the documentation of the history of these institutions.

${ }^{16}$ L. Ruiz De Elvira, Vers la fin du contrat social en Syrie. Association de bienfaisance et redéploiement de l'Etat (2000, 2011) (Paris: IISMM-Karthala, 2019). 
transfer of models occurred between Palestine and Transjordan? How did these associations shape the social space in the country and especially its capital and ensure the Orthodox laity a certain political and communal space?

\section{Orthodox Laity in the Emirate of Transjordan: Developing Diplomatic Ties in a Political Sphere in Reconfiguration}

The establishment of post-Ottoman states transformed the political and social role of missionaries. If the latter had been marginalised during the Ottoman period, their affinity with the Mandate powers encouraged the development of their institutions in the new states. Thus, as the Greek Orthodox patriarchate was facing a financial crisis and conflict between its higher clergy and laity, how did the latter use cultural diplomacy to address the Mandate authorities and the government of Transjordan? In Transjordan as in Palestine, the Orthodox Church asserted its local nature (maballi). ${ }^{17}$ Its structures adapted to those of the state and the church fully subordinated itself to state legislation. ${ }^{18}$ In the Emirate of Transjordan, the political authorities endorsed the election of the Patriarch and approved the clerics appointed on the national territory. During the interwar period, the policies of the Transjordanian government and of the Mandate authorities toward the Greek Orthodox Church should be analysed considering the conflict between laity and higher clergy but also the question of the holy places of Jerusalem. ${ }^{19}$

\section{Orthodox Laity During the Interwar Period: Regional Networks and Circulations}

Until the second half of the nineteenth century, and the arrival of Latin missionaries, most of the Christians of Ottoman Transjordan were members of the Greek Orthodox Church. From this period onwards, a conflict over the question of arabisation opposed the Orthodox laity and lower Arab clergy to the Greek higher clergy. In the late nineteenth and early twentieth centuries, and with the promulgation of the Ottoman constitution in 1908, Orthodox laity called for greater democratisation in the management of the Patriarchate of Jerusalem and for gradual arabisation of the higher clergy. The Arab members of the church requested the abolition of the Ottoman rule of 1875, which gave to the Greek clerical hierarchy of the Brotherhood of the Holy Sepulchre almost exclusive prerogatives in the election of the Patriarch of Jerusalem. A committee of priests and Arab notables was established and called for the application of article 111 of the Constitution which encouraged

\footnotetext{
${ }^{17}$ Chatelard, Briser la mosaïque, 160.

${ }^{18}$ T. Ware, The Orthodox Church (Harmondsworth: Penguin, 1963).

${ }^{19}$ Chatelard, Briser la mosä̈que, 160; R. Abujaber, Arab Christianity and Jerusalem (London: Gilgamesh, 2012).
} 
the establishment of a community council in each qada'. ${ }^{20}$ The rejection of this project by the Greek Orthodox Patriarch led to sharper tensions, including a boycott of masses, demonstrations and petitions. ${ }^{21}$

After 1917, with the fall of the Russian Empire, the missionary efforts of the Imperial Orthodox Society stopped. ${ }^{22}$ A financial commission was convened to assess the situation of the Greek Orthodox Patriarchate and concluded its financial bankruptcy. As a result, some waqf property was sold and the Orthodox Patriarchate of Jerusalem placed under trusteeship. ${ }^{23}$ After the fall of the Ottoman Empire, debates intensified. The demands of the laity and notables went from Arabisation of the hierarchy to the development of communal institutions in order to allow the schooling of Orthodox children away from Protestant and Catholic missionary schools. The Arabisation issue gradually became a central demand connected with the Arab nationalist struggle. ${ }^{24}$ This movement spread from the urban centres of Palestine to Transjordan, led by well-known Arab nationalists engaged against Zionism such as Khalīl al-Sakākīnī and 'Isā al-'Isā (Robson, 2011). ${ }^{25}$ In June 1923, during the sixth Palestinian Arab Congress, intellectuals involved in this Orthodox controversy, such as 'Isā al-'Isā and Ibrāhīm Shammās, presented a petition asking the congress to support the Orthodox struggle. ${ }^{26}$

In this context, an Orthodox fraternity (jama iyyat al-ikhā al-urthūduksiyya) was created with local committees in the parishes dealing with local matters. In 1923, the first Arab Orthodox Congress was organised in Haifa under the authority of Iskandir Kassāb and Ya 'qūb Farrāj, gathering delegates from all the Palestinian and Transjordanian local committees. The latter endorsed a number of decisions concerning the organisation of the church and the need to appoint an Arab metropolitan for Transjordan. The Palestinian local committees (27) were far more numerous than those from Transjordan (4). ${ }^{27}$

${ }^{20}$ D. Hopwood, The Russian Presence in Syria and Palestine 1843-1914: Church and Politics in the Near East (New York: Oxford University Press, 1969), 197.

${ }^{21}$ Chatelard, Briser la mosä̈que.

${ }^{22}$ Hopwood, The Russian Presence in Syria and Palestine; E. Astafieva, "La Russie en Terre Sainte: le cas de la Société Impériale Orthodoxe de Palestine (1882-1917)," Cristianesimo nella storia 1 (2003): 41-68.

${ }^{23} \mathrm{~K}$. Papastathis, "Church Finances at the Colonial Age: The Orthodox Patriarcate of Jerusalem Under British Control, 1921-1925," Middle Eastern Studies 49, no. 5 (2013): 712-731.

${ }^{24}$ Chatelard, Briser la mosainque; S. Khoury and N. Khoury, A Survey of the History of the Orthodox Church of Jerusalem (Amman: Dar al-Shorouk, 2002).

${ }^{25}$ L. Robson, "Communalism and Nationalism in the Mandate: The Greek Orthodox Controversy and the National Movement," Journal of Palestine Studies 41, no. 1 (2011): 6-23; Chatelard, Briser la mosaïque.

${ }^{26}$ Robson, Colonialism and Christianity in Palestine, 81.

${ }^{27}$ There were 4 local committees in Transjordan: Huṣn, al-Salț, al-Karak and Mādabā which sent the following representatives: Dakhl al-Mūsā, Sulaymān 'Abdu (Huṣn), priests Ayyūb and Ibrāhīm (al-Salț), 'Isā al-Madānāt, Jādallah al-Sanā' and Salama al-Sharayḥa (al-Karak), Ya'qūb Jamiān (Mādabā) (Khoury, A Survey of the History of the Orthodox Church of Jerusalem, 204). 
The congress led to the constitution of an executive committee composed of seven Palestinians and three Transjordanians. The latter entered into an ongoing conflict with the successive Patriarchs. ${ }^{28}$

The authorities of the British Mandate and of the Government of Transjordan were asked for mediation both by lay people and the Patriarchate. In a context of political and religious reconfiguration, the Arab laity used cultural diplomacy, through the development of its associative network as a powerful tool to extend its activity in Palestine and in Transjordan. The representatives of the British Mandate, who launched a progressive confessionalisation of the political sphere in the Emirate of Transjordan and Palestine, especially after the creation of the Supreme Muslim Council, ${ }^{29}$ unsuccessfully attempted to interfere in this conflict. In 1926, the BeltramYoung commission of inquiry mandated by the British authorities recommended that members of the Brotherhood of the Holy Sepulcher adopt the Palestinian nationality to limit foreign interference. Its conclusions encouraged lay people to establish educational and charitable associations. ${ }^{30}$ Those recommendations were rejected by the Patriarchate as the conflict between laity settled into time with the organisation of several other congresses of Orthodox laity and notables in 1941 and 1958.

Thus, associations allowed the development of Orthodox cultural and educational activities in Palestine and Transjordan. Through these associations, lay people got involved in the political space and elaborated solidarity networks. In the Emirate of Transjordan, the Orthodox notables mainly concentrated on developing a communal space in the new capital, Amman, thanks to solidarity networks and cultural diplomacy.

\section{Claims for Cultural and Educational Facilities in the New Capital}

From the second half of the nineteenth century onwards, Catholic and Protestant missions settled in the main cities of Ottoman Transjordan (al-Salt, al-Karak, Mādabā, 'Ajlūn, etc.) through to the development of education and medical services. Latin missionaries accused the Greek Patriarchate of having abandoned their followers. However, these missionary policies competed with the initiatives of the Imperial Orthodox Society. The latter was founded in Russia in 1882. It opened many village schools and supported church construction on both sides of the Jordan River. ${ }^{31}$ Not recognised by Ottoman

\footnotetext{
${ }^{28}$ Khoury, A Survey of the History of the Orthodox Church of Jerusalem, 329-331.

${ }^{29}$ U. M. Kupferschmidt, The Supreme Muslim Council: Islam Under the British Mandate for Palestine (Leiden; New York; Copenhagen: Brill, 1987); First Name Added: Roza I. M. El-Eini, Mandate Landscape: British Imperial Rule in Palestine, 1929-1948 (London and New York: Routledge, 2006); N. Neveu, "Les politiques des lieux saints et la topographie sacrée dans le sud de la Jordanie, XIXe-XXe siècles" (PhD diss., Paris, EHESS, 2013).

${ }^{30}$ Chatelard, Briser la mosaïque.

${ }^{31}$ Astafieva, "La Russie en Terre Sainte."
} 
authorities and subject to hostility from the Greek Orthodox Patriarchate, the initiatives of the society were limited. During World War I, Ottoman authorities closed down all the schools and institutions of the Society, just like those of other missionary institutions. ${ }^{32}$

From the 1890s onwards, the Orthodox Patriarchate tried to counter these various missionary advances by building or renovating churches and developing its school network. ${ }^{33}$ In al-Karak, the school for girls was opened in 1898 and the church bell tower was renovated in 1911. ${ }^{34}$ However, the financial crisis experienced by the Patriarchate after World War I stopped these activities. In addition, Orthodox schools were much less well-endowed than their missionary counterparts in terms of infrastructures, training staff and curriculum. The local teachers did not enjoy the same prestige and level of training as foreign missionaries. ${ }^{35}$ Moreover, without a proper Greek Orthodox women's congregation, the development of schools for girls remained limited. In the 1920s, there were only 16 Greek Orthodox schools in Palestine and Transjordan with around 800 pupils. ${ }^{36}$ Thus, many Orthodox in the region chose to send their children to missionary schools while struggling at the same time for the development of a quality Orthodox educational system. In addition, there were no Orthodox colleges or universities in the Greater Syria region, although few young Transjordanians completed high school before World War I. ${ }^{37}$

Thus, in the aftermath of World War I, as Amman and the Emirate of Transjordan became a new missionary front, the Orthodox community found itself in a paradoxical situation: it was the biggest Christian community of the country but deprived of schools and churches in the capital of the new State. In 1922, Amman became the capital of the Emirate of Transjordan, whereas a year before it was not even one of the administrative centres created by the Mandate authority, in contrast to 'Ajlūn, al-Salt or al-Karak for instance. In the 1920s, religious infrastructures were lacking in Amman. The city became an outpost of missionary politics in the Emirate of Transjordan. The construction of much infrastructure followed the expansion of the city to the districts of Wast al-Balad, Jabal Amman, Jabal al-Lweibdeh and Jabal al-Ashrafiyya. From 1923, one of the first projects of Emir Abdallah was the construction of a mosque, on the ruins of the old Umayyad one. Then, under the authority of the Latin Patriarchate, a Latin church was built (1924) and

\footnotetext{
${ }^{32}$ Hopwood, The Russian Presence in Syria and Palestine, 101-109, 134-135.

${ }^{33}$ E. Rogan, Frontiers of the State in the Late Ottoman Empire (Cambridge: Cambridge Middle East Studies, 1999), 43-44.

${ }^{34}$ T. C. Cumhurbaşkanlığı Devlet Arşivleri Başkanlığı, Irâde ve adliye, S., 25 2/9, December 2, 1911.

${ }^{35}$ Chatelard, Briser la mosaïque.

${ }^{36}$ Khoury, A Survey of the History of the Orthodox Church of Jerusalem, 218.

${ }^{37}$ Hopwood, The Russian Presence in Syria and Palestine, 153; Chatelard, Briser la mosaique, 164.
} 
later a Melkite church (1931), in Jabal al-Lweibdeh. As Latin, Protestant and Melkite missions were sent all over the country, many health centres and hospitals opened, such as the Italian hospital (1926) and the hospital of the Church Missionary Society (1927). They were both located in Jabal al-Ashrafiyya.

The construction of Orthodox institutions only started in the late 1930s at the instigation of lay people who settled in Amman. They developed slowly due to funding limitations. Until the 1950s, most of the Orthodox families of Amman were sending their children to the school of the Church Missionary Society. Thus, members of prominent families developed a political network, especially with the representatives of the British Mandate in order to favour the development of a communal space within the capital but also to promote cultural activities. Thanks to this political network and to the cultural activities of their associations they ensured themselves a political role and visibility.

\section{Orthodox Laity and the Mandate Representative: Creating Political Ties}

From 1922 onwards, Amman became the administrative and economic centre of the country. The development of the city was carried out in parallel with the construction of the state. Unlike most cities, its expansion was not due to its economic functions but reflected the political circumstances of its creation. ${ }^{38}$ During the interwar period, Amman and its region attracted migrants from Syria, Palestine, Lebanon and Iraq, but also internal migration from al-Salt and al-Karak. The main factor in this migration was Amman's status as seat of the government. According to Raouf Abujaber, around 400 Christians moved from al-Salt to Amman in the 1920s. ${ }^{39}$ In this context, the Abujabers, a prominent family of traders from al-Salt and Yādūda, settled in Amman. "Awda al-Qusūs who was a judge for the region of al-Karak, trained in the Greek Orthodox school of this city, settled in Amman in the 1920s because of his involvement in the political life of the Emirate. Both families were involved in the activities of the Orthodox laity and developed initiatives in Amman. The extension of the city from Wast al-Balad to the districts of Jabal Amman, Jabal al-Lweibdeh and Jabal al-Ashrafiyya went with the development of religious, cultural and political infrastructures. The competitive topographies which developed during the interwar period indicate the pivotal role of the new capital in terms of cultural diplomacy.

In the early 1920s, according his diaries, John Philby, the High Commissioner of the British Mandate from 1921 to 1924, established privileged relationships with members of Christian prominent families, especially

\footnotetext{
${ }^{38}$ E. Rogan, "The Making of a Capital: Amman 1918-1928," in Amman: Ville et Societé, eds. J. Hannoyer and S. Shami (Beirut: CERMOC, 1996), 89-107.

${ }^{39}$ Abujaber, Al-Nabda al-'arabiyya al-urthûduksiyya.

${ }^{40}$ R. S. Abujaber, Pioneers over Jordan, The Frontier of Settlement in Transjordan, 1850-1914 (London: I.B. Tauris, 1989).
} 
Greek Orthodox ones. Thus, in both Transjordan and Palestine, Orthodox laity turned to representatives of the British Mandate, asking for support and the maintenance of Orthodox institutions. ${ }^{41}$ Some passages of John Philby's diaries point to what was perceived as a weakness of Emir Abdullah in his relationship with the Christians. In this context, many prominent Christian figures came to complain to John Philby about the situation of their community. For instance, on 19 July 1922, Sa'ad Abujaber and 'Isā al-Qa'wār, representatives of the Christian families of Yādūda ${ }^{42}$ visited the British official to complain about abuses committed against their land by a Bedouin tribe. John Philby points out:

My visitor declared that it is no use protesting to the Amir as in such matters they never got any change out of him and the government. ${ }^{43}$

John Philby's role as mediator reflects the low representation of local notabilities in the government of Transjordan and their distance from certain circles of influence, mostly those of Syrian nationalists. Thus, in a context of political change in the framework of the new State, threatening their local influence, these notables sought the support of the representatives of the Mandate administration. On 21 July 1922, a similar interview was conducted between John Philby and 'Awda al-Qusūs, a prominent notable from the city of al-Karak and a politician well known for the publication of his Memoirs ${ }^{44}$ :

In the course of our conversation he criticized the methods of the governments and expressed great dissatisfaction on the part of most of Christian community against the way they were being treated and there is no doubt that there is a good deal of truth in his criticism. At the same time I pointed out to him that if the Christian community which was a minority wished to remain in TransJordan it must realize the necessity of being on the most friendly terms with the Government and the Arabs around it. ${ }^{45}$

'Awda al-Qusūs probably refers in this quotation to two conflicts that opposed members of two tribal alliances in al-Karak including Christian families between 1921 and 1922. His comments reflect his opposition to Emir Abdallah's measures to resolve these conflicts. John Philby was considered as a privileged mediator for the Orthodox Christian notables. He also benefited

\footnotetext{
${ }^{41}$ Robson, Colonialism and Christianity in Palestine, 83.

${ }^{42}$ Yādūda is a village located between Amman and al-Salț. It was established in the late nineteenth century by Christian families of al-Salt, mostly Orthodox.

${ }^{43}$ Saint Anthony's college, GB 165-0229 Philby Collection, 1/5/3/3 Transjordan Diary, Vols. 3 and 5, File 3 of 4 (vol. 5, pp. 149-208).

44 'Awda Slimān al-Qusūs al-Halasā, Mudhakarāt wa 'awraq-bu (Memoirs and papers), eds. Nāîf Jūrj al-Qusūs al-Halasā and Ghassān Slāma al-Shawārb al-Halasā, 28.

${ }^{45}$ Saint Anthony's college, GB 165-0229, Philby Collection, 1/5/3/3 Transjordan Diary, Vols. 3 and 5, File 3 of 4, July 2, 1922.
} 
from this role to structure an opposition to Emir Abdullah and against Syrian nationalists based on Transjordanian notables, including 'Awda al-Qusūs. ${ }^{46}$ In fact, since the early 1920s, missions were also used for political matters in order to limit the claims and influence of Arab nationalists close to the Transjordanian government such as members of the Independence Party, Hizb al-Istiqlāl. ${ }^{47}$

John Philby's status must be analysed considering two characteristics of the TransJordanian political field in the early 1920s. First, the poor integration of local notables within the first Transjordanian governments would have led them to seek alternative spaces to impose their claims. Then, many Christians had actively participated in the Arab nationalist movement. The confessional issue was maybe mobilised by the Orthodox notables in a way to defend their interests and those of the social group they represented. These episodes thus attest to a reconfiguration of the political field, in favour of a territorialisation ${ }^{48}$ and confessionalisation of political identities. ${ }^{49}$ One aspect of the confessionalisation process was the creation of specific legal and juridical measures concerning Christians in Transjordan as the legal status of Christians in 1933. The stake for the Orthodox laity was to affirm its role within the political and social dynamics of the newly created state and ensure its community a communal space within the capital. The Orthodox community and its institutions were therefore characterised by their openness to Transjordanian society. It was involved in fields that went beyond the charitable or educational sectors.

\section{The Orthodox Notables in Transjordan and the Development of the Arab Orthodox Nahda Association}

As mentioned above, after the First World War, the Greek Orthodox Church experienced an intense financial crisis. Due to financial limitations, the church could not develop many schools or build new churches in the Emirate of Transjordan. The Orthodox Church also could not counter the Protestant, Latin and Melkite missionary offensive. For all these reasons, the interwar

\footnotetext{
${ }^{46}$ M. Abu Nowar, The History of the Hashemite Kingdom of Jordan. Volume 1: The Creation and Development of Transjordan, 1920-1929 (Oxford: Ithaca Press Oxford, 1989).

${ }^{47}$ The party was banned in 1921 and its main leaders were sent to exile. B. Anderson, Nationalist Voices in Jordan: The Street and the State (Austin: University of Texas Press, 2005).

${ }^{48}$ The term territorialisation refers to the creation of new religious territories, real or symbolic (S. Andézian, "Introduction - Fondations des lieux de culte," Archives de sciences sociales des religions 151 (September-October, 2010). This process involves different stages of spatial anchoring: appropriation and delimitation of a given territory, construction of a building and formation of a community of the faithful, administrative redistribution, etc.

${ }^{49}$ Neveu, "Les politiques des lieux saints."
} 
period appeared to Orthodox notables as a pivotal period to establish local authority in Amman and in the Emirate of Transjordan through associations and cultural diplomacy.

\section{The Foundation of the Arab Orthodox Nabda Association: A Palestinian Connection?}

In Palestine, the first forms of associations appeared in the late nineteenth century as charities and cooperatives. The Orthodox Philanthropic Foundation was founded in Jaffa in 1879 and encouraged the opening of several clubs and associations. There were three associations in Acre at the beginning of the twentieth century which activities focused on cultural publications and charitable projects. The Ottoman Constitution of 1908 recognised the right to establish associations and in 1908, the National Association for Cultural Promotion was created in Jaffa for the education of youth. The first Ottoman law legislating associations was enacted in 1909. ChristianMuslim associations developed with a clear political agenda (Arab rights, against Zionism), such as the al-Ahliyya association in Jaffa. In 1918, al$n \bar{a} d \bar{\imath}$ al-'arabī (the Arab Club) was also founded in Jerusalem. In addition, in Palestine, Orthodox intellectuals were deeply involved in the development of the press, such as the newspaper Al-Karmil, founded in 1908 by Najib Nassar, Al-Dustur, founded in 1910 by Khalīl al-Sakākīnī, or Falastin, founded by 'Isā al-'Isā in 1910. ${ }^{50}$ Matters such as Arab nationalism, the fight against Zionism or Orthodox controversies were discussed in these newspapers.

During the interwar period, the prominent families in the Mandate of Palestine and in Transjordan were closely connected through economic, cultural and political networks. In 1923, The Arab Orthodox Nahda Association was among the first associations to be funded in the Emirate of Transjordan. On April 19, 1928, the Organic Law for Transjordan was published. It represented a first draft of the constitution of the new State and augured greater State intervention in all matters. ${ }^{51}$ The Organic Law stressed the right of every Transjordanian to practise their religion "according to their traditions" (article 10) and of the different minorities to found private schools (article 14). One of the articles also concerned the right to found associations. The Arab Orthodox Nahda Association was officially recognised on 14 December 1929 with 'Awda al-Qusūs as president and 'Amin Qa'wār as vice president.

In the 1930s, associations such as al-Maqāṣid al-Hijaziyyah Association (1931) and the Circassian Ikhwan Association (1932) were created, followed by others such as the Jordanian Youth League and the Association of the Red Freedom in 1937 (more politically oriented) and the Women's

\footnotetext{
${ }^{50}$ Robson, Colonialism and Christianity in Palestine, 86-87.

${ }^{51}$ National Library of Jordan, Official Gazette, 188, 19 April 1928.
} 
Social Solidarity Society, founded in $1944 .^{52}$ As Seteney Shami states, "ethnic associations appeared as new arenas of interactions" to strengthen social cohesion. ${ }^{53}$ The Orthodox associations aimed to encourage the creation of a communal space within the capital but also to promote political and cultural activities. These clubs had the same social function as in Palestine "to bond kinship groups" with a certain influence of "class and status networks". 54

Orthodox notables played a central role in supporting the creation of these associations. These families mainly came from al-Karak (the Qusūs family), al-Salt (the Abujaber family) and 'Ajlūn/Irbid (the Qa'wār family). 'Awda al-Qusūs (1877-1943) was the first founder of the Arab Orthodox Nahda Association. During the Ottoman period, he was a judge in the bidāiyya tribunal of al-Karak and then joined the General Council of the vilayet of Suriyya. After the creation of the Emirate, he was involved as a judge in several types of courts and tribal conflict regulations. He was a member of the National Party and from the late 1920s onwards held political office several times. His memoirs remain one of the richest sources of the social history of Transjordan. From the early 1920s, one of the very first preoccupations of 'Awda al-Qusūs was the opening of an Orthodox school in Amman. 55

In order to develop its activity in the Emirate of Transjordan, the representatives of the future association had to gather the support of the representatives of the Transjordanian government through cultural activities. For instance, in a letter of 2 August 1921, the King's Advisor thanks 'Awda al-Qusūs for his effort in diffusing science and knowledge in the country. He mentions in particular the diffusion of the content of Shams al-ma $\bar{a} \overline{r i f}^{\overline{5}}$ and some knowledge about the so-called Oriental sciences. ${ }^{57}$ This letter was sent before the creation of the association and indicates the role played by cultural activities organised by Arab Orthodox representatives in developing political and diplomatic ties with members of the government of Transjordan. If the letter remains quite vague on the content of the cultural and intellectual activities of the association it apparently refers to the promulgation of classical knowledge from the literate culture of the time in Palestine and Transjordan.

\footnotetext{
${ }^{52}$ E. Harmsen, Islam, Civil Society and Social Work: Muslim Voluntary Welfare Associations in Jordan Between Patronage and Empowerment (Leiden and Amsterdam: Amsterdam University Press, 2008).

${ }^{53}$ S. Shami, "The Circassians of Amman: Historical Narratives, Urban Dwelling and the Construction of Identity," in Amman, ville et sociétéi, eds. S. S. Hannoyer Jean and S. Shami (Beirut: CERMOC, 1996), 317.

${ }^{54}$ S. Tamari, Mountain Against the Sea: Essays on Palestinian Society and Culture (Berkeley: University of California Press, 2008), 43.

${ }^{55}$ Abujaber, Al-Nabda al-'arabiyya al-urthûduksiyya, 150.

56 Shams al-ma'ārif is a manuscript of the thirteenth century written by Ahmad al-al-Būnī, an Egyptian scholar. It is considered the most important textbook for Islamic essoteric spirituality.

${ }^{57} \mathrm{~A}$ copy of the letter is published in Abujaber, Al-Nabda al-'arabiyya al-urthûduksiyya, 150.
} 
The Orthodox Nahda Association was directly associated by its name with the movement launched by Khalīl al-Sakākīnī and Yūsuf and 'Isā al-'Isā. ${ }^{58}$ Indeed, the Palestinian and Transjordanian Orthodox community, led by significant figures such as Khalīl al-Sakākīnī (1878-1953), increasingly shaped their struggle as a regional political movement. In 1913, Khalīl al-Sakākīnī wrote a pamphlet entitled al-nahda al-urthūdukisiyya fì Filasțin (the Orthodox Renaissance in Palestine) in which he highlighted the quality of the Arab Orthodox movement. ${ }^{59}$ However, during the 1920s and 1930s, the debate within the Orthodox laity in Transjordan mirrored that of their Palestinian counterparts. For al-Sakākīn̄i, communal identification and nationalism were not compatible. Other Palestinian intellectuals as Ya'qūb Farrāj, 'Isā al-'Isā or Emil al-Ghurī considered their articulation as a way to give a pivotal role to the Orthodox movement within the political life of Palestine. ${ }^{60}$ The strategy developed by the leader of the Arab Orthodox Nahda Association was part of the same political register.

From the 1920s, the first activities of the association consisted of organising debates in Amman about Zionism in Palestine, but also about nationalism. In his book on the history of the Arab Orthodox movement in Transjordan, Raouf Abujaber mentions the role of 'Awda al-Qusūs during the 1929 riots and massacre in Palestine. He called for a boycott of products and trading relationships with Jewish merchants from Tel Aviv and promoted trading with the British. Al-Qusūs was defending the development of a national trade based on Syrian and Palestinian merchants. ${ }^{61}$ The activities of the Arab Orthodox Nahda Association and its representatives were mainly focused on cultural and political issues. The government of Transjordan sought to promote Arab culture and knowledge, which became an important asset for Arab Orthodox associations in order to obtain backing for their activities and for the claims of their political representatives concerning political and communal issues. In the 1920s, the association grew in Amman thanks to the links its leaders established with representatives of the British Mandate and of the government of Transjordan. In Transjordan, it was different as in Palestine, "Unlike in Beirut, Damascus, and Cairo, where literary cafés served as a venue for intellectual debates and belonged to competing political groups, in Palestine during the Mandate, cultural and confessional clubs took over this role". ${ }^{62}$

The second Orthodox conference took place in Jaffa in 1931 under the chairmanship of 'Isā al-'Isā with 8 representatives of the Transjordanian

\footnotetext{
${ }^{58}$ Khalaf, Les Mémoires de 'Issa al-'Issa.

${ }^{59}$ Robson, Communalism and Nationalism in the Mandate, 15.

${ }^{60}$ Robson, Communalism and Nationalism in the Mandate, 16.

${ }^{61}$ Abujaber, Al-Nabda al-'arabiyya al-urthîduksiyya, 150-151.

${ }^{62}$ Tamari, The Mountain Against the Sea, 188.
} 
committees of Irbid/'Ajlūn, al-Karak, al-Salṭ, Madābā, 'Ammān and Huṣn. ${ }^{63}$ The conference was organised in a specific context, after the death of the Greek Orthodox patriarch Damanios which lead to a revival of the claims of the Arab Orthodox laity concerning the organisation of the church. They started to demand modern electoral and constitutional reforms and called for a boycott of the patriarchal elections. ${ }^{64} \mathrm{~A}$ memorandum was sent by the Orthodox Arab executive committee to the government of Palestine in October 1931 requiring the implementation of the Bertram Young commission of 1926. A similar memorandum was sent to Emir Abdallah by the Orthodox representatives of Transjordan. The Emir answered this memorandum in a letter in which he stated his support for the claims of the Arab Orthodox and especially concerning the election of an Arab Patriarch. ${ }^{65}$ Cultural diplomacy within the Emirate of Transjordan and at the regional scale allowed the Arab Orthodox to find political support that they could mobilise according to the circumstances and the nature of their claims. It also granted them a political presence they wished to embody with the creation of a communal space within the capital of the Emirate of Transjordan.

\section{The Arab Orthodox Nabda Association: Creating a Communal Urban Presence}

From the 1920s onwards, one of the Orthodox Nahda Association's main goals was to promote the religious activities of the Orthodox community and a communal space in Amman. ${ }^{66}$ In 1932, the Orthodox Nahda Association decided to build a church in Amman, supported by private funding. In his book on the history of the Arab Orthodox movement in Jordan, Raouf Abujaber provides a copy of a decision of the board of the Arab Orthodox Nahda Association, noting that:

On Saturday, July 30, 1932, the Arab association gathered on the invitation of the board of directors and its administration and ordered the establishment of a church. It was decided by agreement to send the priest Sulaymān 'Isā of the Orthodox community in Amman to the villages of Transjordan and Palestine in order to extend the aid and benevolence of all Orthodox philanthropists $[\ldots]^{67}$

The project of building a church in Amman emerged independently from the authority of the Greek Orthodox Patriarchate but with the support of the lower Arab clergy. The project for a church depended on private funding

\footnotetext{
${ }^{63}$ The fourth and fifth Orthodox Congress took place in 1956 and in 1992.

${ }^{64}$ Robson, Colonialism and Christianity in Palestine, 88.

${ }^{65}$ Khoury, A Survey of the History of the Orthodox Church of Jerusalem, 250.

${ }^{66}$ Abujaber, Al-Nabda al-'arabiyya al-urthûduksiyya.

${ }^{67}$ Abujaber, Al-Nabda al-'arabiyya al-urthûduksiyya, 154.
} 
from Palestinian and Transjordanian donations. Sulaymān 'Isā was also in charge of entrusting these funds to the bank. In 1932, the board of the association also asked Mīkhā̄îl $\mathrm{Qa}^{6}$ wār to look for a proper location in which to build the church in Amman, and it was decided that it should be located close to the neighbourhood of al-Ashrafiyya where the Italian hospital, the Latin church and the Hospital of the Church Missionary Society were already sited. The church was located in proximity to the sayl, the stream that crossed downtown Amman at this time. The land was registered under the name of the Association. It was bought from a Circassian family, as the Circassians were the first to resettle in Amman in the late nineteenth century.

The Greek Orthodox Church was thus characterised by a will to develop its communal space in the capital out of regional funding. ${ }^{68}$ This territorialisation process reflects the reality of the communal borders which did not correspond to the national ones, but were marked by interconnections between members and representatives of Arab Orthodoxy. However, this first attempt to build a church was interrupted for economic reasons and the project remained one of the main preoccupations of the Association even though the first plans of the edifice had already been drawn. The association also planned to build a school on land adjacent to the church.

In 1943, Ḥanā al-Qusūs, physician, became the president of the association. He was also a prominent figure of the Arab Orthodox movement in Transjordan who was born in al-Karak in $1885 .{ }^{69}$ That same year, in 1943, a branch of the association opened in Fuhayṣ, a village located about 20 kilometres from Amman and populated by a majority of Orthodox. Moreover, members of the Association extended their ambition of building churches for their community to include Zarqa. ${ }^{70}$ During this period, the Association continued its initial cultural activities yet also started to promote more sports and spread to other cities and villages of the country.

From the 1930s, Sa'ad Abujaber increasingly took a prominent place within the Orthodox laity and associations, especially by involving himself in the project of constructing a Greek Orthodox church in Amman. ${ }^{71}$ He belonged to an influential family from al-Salt that established al-Yadūda in 1860 and whose activities had flourished in the early twentieth century through the development of agriculture and the grain trade in the Balqa

${ }^{68} \mathrm{G}$. Chatelard, "The Constitution of Christian Communal Boundaries and Spheres in Jordan," Journal of Church and State 52, no. 3 (Summer 2010): 476-502.

${ }^{69} \mathrm{Hana}$ al-Qusūs was a physician who had completed part of his studies at the preparatory school of the Greek Orthodox Patriarchate of Jerusalem and then at French Faculty of Medicine of Beirut and Paris. After serving in the Ottoman army as a doctor, he became a member of the health department of the Emirate of Transjordan.

${ }^{70}$ Abujaber, Al-Nabda al-'arabiyya al-urthúduksiyya, 163-164.

${ }^{71}$ Hana al-Qusūs and Raouf Abujaber, both entrepreneurs, replaced their relatives at the head of the Association. From the 1920s, notables from al-Salț, Irbid, al-Karak or Ma'ān settled in Amman and contributed to its spatial expansion and its cultural and intellectual life. 
region. ${ }^{72}$ The Abujaber family developed strong economic ties with Nablus since the nineteenth century. Thus, out of his economic and political connections, he could mobilise kinship networks with Palestine.

In 1947, Sa'ad Abujaber became responsible for the committee in charge of the construction of the church in Amman. The vice president was Khalil al-Madānāt. The construction work on the church began in 1947, thanks to a donation of 5000 pounds from the Orthodox Monastery of Jerusalem. ${ }^{73}$ The edifice was inaugurated in 1948 and became a central space in the life of the community. Later, in addition to this church, the association also acquired a building to organise cultural activities, especially for young people and scouts. A third building was purchased for gatherings and parties.

The Orthodox notables played an important role in developing cultural institutions in the capital and the different cities and villages of the country. Due to the conflict between the laity and the Patriarchate much of this infrastructure (schools, churches and hospitals) were built thanks to private funding. Notables would fund a church, building, furniture or ceremonies and take care of their maintenance. The local committees under the supervision of the lay people are, until today, in charge of many churches in Jordan. Women played an important role within these committees with examples such as Hind al-Qa'wār, who is at the time of writing still in charge of the maintenance of al-'Abdalī church in Amman.

The Arab Orthodox Nahda Association contributed to developing a social and intellectual life in Transjordan and more broadly in the region. Its activities were rooted in political debates, including Arab nationalism, the struggle again Zionism, and eventually against communism. These institutions were meant to shape the religious but also cultural and political life of the community. In Amman, members of the Association faced difficulties in developing communal space and education. This case study therefore underlines the limits of cultural diplomacy at the local level. The political authorities were so constrained by their relationship with the Patriarchate of Jerusalem that they could not free the members of the association from the economic issues affecting the development of their activities in the country.

This political and social function developed with the arrival of Palestinian refugees in Jordan after the Nakba. These newcomers were already very involved in the community's social and organisational life within Palestine, ${ }^{74}$ and they continued these activities in Transjordan. The case study of Amman reveals how lay people played a central role from 1920 onwards in the organisation and structure of the Orthodox community in Transjordan and Palestine.

\footnotetext{
${ }^{72}$ Abujaber, Pioneers over Jordan.

${ }^{73}$ Abujaber, Al-Nabda al-'arabiyya al-urthûduksiyya, 164.

${ }^{74}$ M. Mack, "Orthodox and Communist: A History of a Christian Community in Mandate Palestine and Israel," British Journal of Middle Eastern Studies 42, no. 4 (2015): 1-17; D. Tsimhoni, "The Greek Orthodox Patriarchate of Jerusalem During the Formative Years of the British Mandate in Palestine," Asian and African Studies 12, no. 1 (1978): 77-121.
} 


\section{Migration and Regional Circulation: Expanding the Arab Orthodox Imprint in Amman}

The role played by associations in promoting cultural activities and sports is still understudied for the case of Transjordan. Yet they constituted places of sociability and contact where political matters such as Arab nationalism were discussed and where special attention was dedicated to young people. Between 1948 and 1967, the West Bank and East Jerusalem were attached to the Kingdom of Jordan from 1946. Some of the notables of Palestine and Transjordan were thus placed under the same political authority, as the Palestinian struggle was central to the political life of the community. In the 1940s, the political life of the Kingdom faced major changes with the attainment of independence and the considerable increase in its population through the annexation of new territories and the arrival of thousands of Palestinian refugees. This political reconfiguration led to the affirmation of a discourse on the new national identity giving a privileged place to Jerusalem. ${ }^{75}$ After the annexation of the West Bank and Jerusalem, the government of Jordan attached greater importance to Christian issues. Its statement in favour of the claims of the Orthodox Arab laity illustrates the tension between their effective cultural diplomacy and the political and diplomatic stakes embodied by the interests of the Greek Orthodox Patriarchate in Jerusalem.

\section{The 1940s and the Change of Diplomatic Paradigm}

From the 1950s, with the annexation of the West Bank, East Jerusalem and its holy sites, the Hashemite monarchy's relations with the religious authorities and institutions in Jerusalem evolved significantly. During this decade, the Prime Minister officially stood for the Arabisation of the higher clergy and patriarchate within the framework of the Arab nationalist struggle. In this time, the Orthodox laity was strongly supported by the government of Jordan and developed its activities and presence within the country. The Orthodox laity continued to approach the Hashemite authorities with a view to gaining support for their claim. The Orthodox laity became strongly politicised from the Fourth Orthodox Congress of 1956 onwards, as they received the support of Arab nationalists and left-wing parties. The Jordanian government, headed by Sulaymān Nābulsī, supported the Arabisation of the Orthodox patriarchate as part of the Arab national cause. ${ }^{76}$

January 1957 and the election of Patriarch Benedictos represented a turn within the diplomatic relations of the Jordanian State with the Greek

\footnotetext{
${ }^{75}$ K. Katz, Jordanian Jerusalem: Holy Places and National Spaces (Gainesville: University Press of Florida, 2005).

${ }^{76}$ Tsimhoni, "The Greek Orthodox Patriarchate of Jerusalem,” 38-39.
} 
Orthodox Patriarchate and laity. In 1957, the Jordanian Parliament approved a new patriarchal settlement that granted most of the claims of the lay people. The settlement was revised in 1958 after the new patriarch proposed another settlement which was approved the same year. While it acceded less to the demands of Palestinian and Transjordanian laity, it was still accepted as it endorsed many of their claims. This regulation, which is still in force today, established the formation of executive boards in all parishes, and the election of a council of lay people to participate in the management of the Patriarchate's affairs alongside the hierarchy. Concerning the higher clergy, the settlement ratified the ordination within three years of two Arab metropolitans for Jordan and the adoption of Jordanian nationality by all members of the synod. From this period onwards, members were required to speak Arabic..$^{77}$ The first Jordanian metropolitan was ordained in 1960.

Jordanian lay people considered this settlement as a first step, after which more of their claims would be taken into account. In the absence of new developments, they remained dissatisfied with this regulation. Indeed, its implementation does impose changes but with relative effectiveness in terms of power dynamics within the Church. Tensions with the Patriarchate therefore persist to this day and explain the importance of associations of lay people in Jordan. The latter were greatly reinforced in the 1950s by the arrival of Palestinian nationalist figures who were widely involved in the development of sports and cultural associations in Palestine.

The 1950s and 1960s revealed both the impact of the powerful cultural diplomacy of the Orthodox laity who succeeded in gaining agreement to some of their claims especially concerning the organisation of their Church and relations with the higher clergy. This period also revealed the limits of this endeavour since the Hashemite rulers were careful not to alienate the Greek Orthodox upper hierarchy in a context in which it claimed sovereignty over the holy sites of Jerusalem and Bethlehem. ${ }^{78}$ The Hashemites therefore took on the role of mediator between the laity and the higher clergy and were concerned about preserving good diplomatic relations with each side. Relations with the Patriarchate were strengthened from the late 1950s onwards thanks to the Patriarch's support for the monarchy during the attempted coups against King Hussein in the 1950s. ${ }^{79}$ In addition, the entry into the Jordanian government of several prominent political figures as representatives of Jerusalem, such as Ya'qūb Farrāj, gave the Orthodox laity a new political and diplomatic centrality as their new associations flourished in Amman in the 1950s.

\footnotetext{
${ }^{77}$ Chatelard, Briser la mosaïque.

${ }^{78}$ Katz, Jordanian Jerusalem.

${ }^{79}$ Anderson, Nationalist Voices in Jordan, 280; D. Tsimhoni, Christian Communities in Jerusalem and the West Bank Since 1948 (London: Praeger, 1993), 42.
} 


\section{From Sunday School to the Educational Association}

In 1948, the Nakba and the creation of the State of Israel led to the departure of hundreds of thousands of Palestinian refugees and the arrival of thousands of them in Jordan. In 1949, the West Bank of the River Jordan, which would be formally annexed to the Hashemite Kingdom of Jordan in 1950, was the main host territory with an estimated 280,000 refugees, followed by the Gaza Strip, then administered by Egypt $(200,000)$, Lebanon $(97,000)$, and Syria $(75,000) .{ }^{80}$ From 1948 to 1967, with Jordan annexing West Bank and East Jerusalem, local churches faced important internal changes-as well as the administrative ones-as they had to welcome new members and provide them with humanitarian support.

During an interview in January 2015, Michel Ewaisse, engineer and current member of the Orthodox Association, stated:

This is the association [the Orthodox Nahda Association] that built the first church in the city centre. [...] After the Nakba and the creation of the State of Israel, it played an important role in welcoming Palestinian refugees and providing them with help (clothing, food, etc.). ${ }^{81}$

Many notables maintained relations with the territories they had to leave. At this time, families such as the Farrāj and the Hanāniyya were important leaders and representatives of the Palestinian national movement, very involved in the Orthodox laity movement. Ya 'qūb Farrāj, for instance, was an eminent political figure, member of the National Defense Party, who had been appointed vice-mayor of Jerusalem in the 1930s and 1940s. The dispersion of these families over the region after the Nakba did not lead to the disappearance of the Orthodox movement and claims. Moreover, some of these Palestinian communal and political leaders settled in Jordan and were involved in politics as representatives of Jerusalem and the West Bank in parliament, such as Anasțās Ḥanāniyya who became Minister of Finance in the 1950s.

The arrival in Jordan of Palestinian members of the Orthodox associations was a turning point in the life of the community there. During the 1950s, the Orthodox associations developed further. Palestinian notables brought to Jordan new associative models they had already developed in Palestine. Thanks to their expertise and networks they opened new cultural association and clubs, mainly in Amman.

Father Qunsțanțin Qarmash, the current priest of the 'Abdalī parish in Amman played a considerable role in this new dynamic. He was born in

${ }^{80}$ J. Al Husseini, "The Arab States and the Refugee Issue: A Retrospective View," in Israel and the Palestinian Refugees vol. 189, eds. E. Benvenisti, C. Gans, and S. Hanafi (Berlin and Heidelberg: Springer, 2007), 253-263.

${ }^{81}$ Interview with Michel Ewaisse, January 25, 2015, Amman. 
1927 in Beit Jala and went to school in Bethlehem. During an interview, he mentioned arriving in Jordan in 1948 to find very limited religious education being provided by Russian clerics in the refugee camps of Jordan. ${ }^{82}$ As mentioned above, until the 1950s, there was no Orthodox school in Amman. Qarmash played a major role in developing the catechism and Sunday schools in the capital. The creation of a school in Amman had been a constant demand of the representatives of the Association and especially 'Awda al-Qusūs since the 1920s. ${ }^{83}$ According to Raouf Abujaber, during the 1930s, the Arab Orthodox Nahda Association opened a school in Amman which could accommodate around 50 boys and girls. ${ }^{84}$

The opening of an orthodox school in the 1950s was a gradual process that also benefited from the dynamic of this first school but also from Sunday classes provided by Qunstantịn Qarmash and his wife after Sunday masses. They organised these classes in a room located close to the church of the neighbourhood of al-Ashrafiyya in Amman. According to Zakī Nūrsī, entrepreneur and a former member of the Arab Orthodox Nahda Association, the idea of developing a Sunday school came from one of his relatives. ${ }^{85}$ The latter had been inspired by the policies developed by the Copts of Egypt during the Coptic renewal. ${ }^{86}$ In Egypt, in the nineteenth century, the concept of Sunday schools was introduced by evangelical missions and became a keystone of the Coptic revival movement. One of the goals of the Sunday school was to strengthen the theological formation of the children, and some of them were encouraged to continue their studies in Lebanon (Balamand) or in Greece. Aside from educational concerns, training local students was considered to be a way to encourage the constitution of a local Arab clergy. The constitution of these Sunday schools is currently considered to have been the first step of developing an Orthodox educational policy in Jordan.

In 1953, the "Orthodox Sunday Schools Society" did not succeed to officially register. After different attempts in the 1950s, "The Orthodox Educational Society" (jamā'iyyat al-thaqāfa wa al-ta'tim al-urthūdukisiyya) was registered on 7 January 1958. Its first president was Fu'ad Q. Yaghnam. The society gathered notables and lower clergy representatives as Qunsțanțin Qarmash. After F. Yaghnam, the other directors included businessmen and political figures as Fu'ad Farrāj, ${ }^{87}$ who were able to mobilise

\footnotetext{
${ }^{82}$ Interview with Qunsțanțin Qarmash, January 12, 2015, Amman.

${ }^{83}$ Abujaber, Al-Nabda al-'arabiyya al-urthûduksiyya, 149

${ }^{84}$ Abujaber, Al-Nabda al-'arabiyya al-urthûduksiyya, 156.

${ }^{85}$ Interview with Zakī Nūrsī, January 16, 2015, Amman.

${ }^{86}$ P. Sedra, From Mission to Modernity: Evangelicals, Reformers and Education in Nineteenth Century Egypt (London: I.B. Tauris, 2011).

${ }^{87}$ Fu'ad Farrāj and his family fled to Jordan in 1948. After studying engineering in Egypt, he became president of the Association of Engineers and Minister in the government of Wasfi al-Tal. He became president of the Orthodox Educational Society in 1990.
} 
their social capital and institutional support to overcome the inadequacies of the Patriarchate in educational and social matters. This association quickly opened an Orthodox secondary school in Amman, which became a popular institution and produced its own textbooks outside the control of the Patriarchate. Then, it developed educational institutions as kindergarten and schools in the neighbourhoods of al-Ashrafiyya and al-Shmaisānī. However, until the 1970s, the school was never really able to compete with the De La Salle School for boys and the CMS School for girls which opened in the 1950s and during the interwar period, and that benefited from their connection with equivalent institutions in Palestine.

In this context, the arrival of members of the Palestinian elite, involved in the political life of the country, drove new dynamics in Jordan. They used their economic, kinship and political ties with Palestine to encourage the development of clubs and associations but also had to rely on prominent members of the Greek Orthodox community in Jordan.

\section{Sporting and Cultural Associations: Family Networks And Know-How}

During the interwar period, many clubs promoting sports and culture developed in Palestine. ${ }^{88}$ Before 1948, there were some 65 athletic clubs in Palestine; about 55 of them were members of the Arab Palestine Sports Federation (APSF).$^{89}$ Many youth associations and clubs had also sprung up in the country. The development of these structures was closely related to the building of resistance to Zionism and British policies. They were spaces of socio-political mobilisation contributing to the nation-building process. ${ }^{90}$ The Orthodox clubs opened in the main cities of Palestine and during the 1940s, a Union of the Orthodox Clubs was created in Palestine, bringing together representatives of the clubs of Jerusalem, Jaffa, Haifa, Ramallah and Acre. Hanā Salāma was elected president of this union during this period.

Many of the Palestinian families which settled in Amman after 1948 came from Jaffa and had been involved in the cultural associations and local committees there. Once settled in Amman, they used these ties to develop communal cultural and sporting activities. In 1952, the Orthodox community received the help of the leader of the Orthodox Club of Jaffa to open a club in Amman under the initiative of Ḥalīm S. Sabā, Bāsīl 'Anāb, George Khunūf and Nicolā Abū Khidr. They were supported locally by Yūsuf al-'Ashar

${ }^{88}$ I. Khalidi, "Sports and Aspirations: Football in Palestine, 1900-1948," Jerusalem Quarterly 58 (2014): 74-88.

${ }^{89}$ I. Khalidi, "Body and Ideology Early Athletics in Palestine (1900-1948)," Jerusalem Quarterly 27 (2006): 44-58.

${ }^{90} \mathrm{D}$. Woroniecka-Krzyzanowska, "State, Sport and Resistance: A Case of Palestinian Sports Clubs in the West Bank," International Review for the Sociology of Sport, Online First (March 2019). 
and Raouf Abujaber who were both already very involved in the different Orthodox associations in the Kingdom of Jordan..$^{91}$

Fawzi Shnoudeh, the former director of the Orthodox club in Amman, mentioned during an interview that the first premises of the club were located in Jabal Amman "where the YMCA is today".92 The development of ties between the Greek Orthodox and Protestant missions was encouraged by representatives of the British Mandate since the 1920s. The Orthodox Club was one of the first structures to encourage sports for young people including, tennis and basketball. Women played a fundamental role in the club by leading committees to support activities for children and organise competitions and training sessions. The Orthodox club quickly became a social space for the elite of Amman and a space where political issues could be debated. The membership grew over the years and the executive committee bought land in Abdoun while the development of this neighbourhood was still in its early stages. The new club was inaugurated in 1972. Today, it counts around 2700 member families or around 11,000 individual members, mostly Orthodox Christian and coming from the economic and political elite of Amman's society. The location of the club and its shifts mirror the changing habits of these social groups.

\section{Conclusion}

The Orthodox case study indicates the need to consider cultural diplomacy from an entangled perspective, at a regional scale. First, the cultural diplomacy developed by the Orthodox laity in Jordan addressed the different layers of religious and political authorities it wanted to affect and influence: from the Mandate authorities to the government of (Trans)Jordan and the Greek Orthodox higher clergy and Patriarchate. For this reason, this cultural diplomacy was polymorphic by definition, as it has to address different interlocutors and goals. The hoped-for results were at some point to guarantee a communal space at a local and regional scale but also to favour social cohesion and nationalist projects. This cultural diplomacy was closely related to the self-definition of the Orthodox presence and action in the region. The latter was characterised by an inclusion within both the local society and political debates but also by specific demands for a communal space and activities. In this respect, members of prominent families shaped the cultural life of the country through the development of different kinds of institutions: clubs, schools, associations, etc.

Moving to Amman and settling there was an important precondition to obtaining social and political status, especially during the first years of the

${ }^{91}$ I. I. Habash, Orthodox club, Al-kitâb al-dhababî, Masîrat al-nâdi al-urthûduksiyya, 19522002 (Amman: National Press, 2005), 12-13.

${ }^{92}$ Interview with Fawzi Shnouded, January 26, 2015, Amman. 
Mandate, as few Transjordanians were involved in the government. For this reason, the activities of the Arab Orthodox Nahda Association focused first on the capital. This reflects the importance of local actors in shaping a social and cultural life in the main cities of Palestine and Transjordan during the interwar period. Cultural diplomacy cannot be considered out of a connected approach of the Orthodox laity of Palestine and Transjordan. Ideas, books and journals were circulating in the region but also funding and political statements. Thanks to these ties and solidarity networks, the Orthodox laity managed to impose itself as an essential interlocutor of the (Trans)Jordanian State. Then, the Mandate witnessed the assertion of a strong Orthodox laity in (Trans)Jordan, concerned about its independence from the Patriarchate. Thanks to cultural diplomacy, this Orthodox laity accessed a political space that guaranteed them a prominent place even after 1948 when the Jordanian State developed stronger diplomatic relations with the Greek Orthodox Patriarchate due to its claim on the holy sites of Jerusalem and Bethlehem.

\section{BIBLIOGRAPHY}

\section{ARCHIVES}

Middle East Center, St Antony's College, Oxford (SAC), Private Papers Collection. National Library of Jordan, Official Gazette.

T.C. Cumhurbaşkanlığı Devlet Arşivleri Başkanlığı, Irâde ve adliye.

\section{REFERENCES}

Abu Nowar, M. The History of the Hashemite Kingdom of Jordan. Volume 1: The Creation and Development of Transjordan, 1920-1929. Oxford: Ithaca Press Oxford, 1989.

Abu-Ghazaleh, A. "Arab Cultural Nationalism in Palestine During the British Mandate." Journal of Palestine Studies 1, no. 3 (1972): 37-63.

Abujaber, R. S. Arab Christianity and Jerusalem. London: Gilgamesh, 2012.

- Pioneers over Jordan, The Frontier of Settlement in Transjordan, 1850-1914. London: I.B. Tauris, 1989.

- Al-Nabda al-'arabiyya al-urthûduksiyya fi 'arja' al-Batriarkia al-Maqdissiyya, 1865-2015, Vols. 1-2. Amman: National Press, 2016.

Al Husseini, J. "The Arab States and the Refugee Issue: A Retrospective View.” In Israel and the Palestinian Refugees Vol. 189, edited by E. Benvenisti, C. Gans, and S. Hanafi, 253-263. Berlin, Heidelberg: Springer, 2007.

al-Qusûs al-Halasâ, A. S., al-Qusûs al-Halasâ, J. N., and Ghassân, S. Mudhakarât wa 'awraq-hu (Memoirs and papers). Not published, n.d.

Anderson, B. Nationalist Voices in Jordan: The Street and the State. Austin, TX: University of Texas Press, 2005.

Andézian, S. "Introduction - Fondations des lieux de culte." Archives de sciences sociales des religions 151 (September-October 2010).

Astafieva, E. "La Russie en Terre Sainte : le cas de la Société Impériale Orthodoxe de Palestine (1882-1917).” Cristianesimo nella storia 1 (2003): 41-68. 
Bocquet, J. Missionnaires français en terre d'islam, Damas 1860-1914. Paris: Les Indes Savantes, 2005.

Bourmaud, P. "Discipline et familiarisation à travers la médecine: une mission médicale à Gaza (1878-1914)." Missions religieuses, missions médicales et "mission civilisatrice” (XIXe et XXe), Histoire, monde et cultures religieuses 1, no. 21 (2012): 81-102.

Chatelard, G. Briser la mosä̈que. Les tribus chrétiennes de Madaba, Jordanie (XIXXXe siècle). Paris: CNRS Editions, 2004.

- "The Constitution of Christian Communal Boundaries and Spheres in Jordan." Journal of Church and State 52, no. 3 (Summer 2010): 476-502.

Dakhli, L. Une génération d'intellectuels arabes. Syrie et Liban (1908-1940). Paris: Karthala, 2009.

El-Eini, Roza I. M. Mandated Landscape. British Imperial Rule in Palestine, 19291948. Londres and New York: Routledge, 2006.

Goff, P. M. "Cultural Diplomacy." In The Oxford Handbook of Modern Diplomacy, edited by A. F. Cooper, J. Heine, and R. Thakur, 419-435. Oxford: Oxford University Press, 2013.

Habash, I. I. Orthodox club, Al-kitâb al-dhahabî, Masîrat al-nâdi al-urthûduksiyya, 1952-2002. Amman: National Press, 2005.

Harmsen, E. Islam, Civil Society and Social Work: Muslim Voluntary Welfare Associations in Jordan Between Patronage and Empowerment. Leiden and Amsterdam: Amsterdam University Press, 2008.

Hopwood, D. The Russian Presence in Syria and Palestine 1843-1914: Church and Politics in the Near East. New York: Oxford University Press, 1969.

Katz, K. Jordanian Jerusalem: Holy Places and National Spaces. Gainesville: University Press of Florida, 2005.

Khalidi, I. "Body and Ideology Early Athletics in Palestine (1900-1948)." Jerusalem Quarterly 27 (2006): 44-58.

- "Sports and Aspirations: Football in Palestine, 1900-1948." Jerusalem Quarterly 58 (2014): 74-88.

Khoury, S., and N. Khoury. A Survey of the History of the Orthodox Church of Jerusalem. Amman: Dar al-Shorouk, 2002.

Kozma, L., A. Schayegh, and A. Wishnitzer. A Global Middle East: Mobility, Materiality and Culture in the Modern Age, 1880-1940. London: I.B. Tauris, 2015.

Kupferschmidt, U. M. The Supreme Muslim Council: Islam Under the British Mandate for Palestine. Leiden and New York; Copenhagen: Brill, 1987.

Mack, M. "Orthodox and Communist: A History of a Christian Community in Mandate Palestine and Israel." British Journal of Middle Eastern Studies 42, 4 (2015): 1-17.

Makdisi, U. Artillery of Heaven: American Missionaries and the Failed Conversion of the Middle East. London: Cornell University Press, 2008.

Mazza, R. "Churches at War: The Impact of the First World War on the Christian Institution of Jerusalem, 1914-1920." Middle Eastern Studies 45, no. 2 (2009): 207-227.

Neveu, N. Les politiques des lieux saints et la topographie sacrée dans le sud de la Jordanie, XIX-XXe siècles. PhD dissertation, Paris, EHESS, 2013. 
_. "Between Uniatism and Arabism: Missionary Policies and Diplomatic Interest of the Melkites in Jordan During the Interwar Period." Social Sciences and Mission, Special Issue: Missions, Powers and Arabization 32, nos. 3-4 (2019): 361-392.

Papastathis, K. "Church Finances at the Colonial Age: The Orthodox Patriarchate of Jerusalem Under British Control, 1921-1925." Middle Eastern Studies 49, no. 5 (2013): 712-731.

Robson, L. Colonialism and Christianity in Palestine. Austin: University of Texas Press, 2011.

- "Communalism and Nationalism in the Mandate: The Greek Orthodox Controversy and the National Movement." Journal of Palestine Studies 41, no. 1 (2011): 6-23.

Rogan, E. "The Making of a Capital: Amman 1918-1928." In Amman: Ville Et Societé, edited by J. Hannoyer and S. Shami. Beirut: CERMOC, 1996.

- Frontiers of the State in the Late Ottoman Empire. Cambridge: Cambridge Middle East Studies, 1999.

Ruiz De Elvira, L. Vers la fin du contrat social en Syrie. Association de bienfaisance et redéploiement de l'Etat (2000, 2011). Paris: IISMM-Karthala, 2019.

Sedra, P. From Mission to Modernity: Evangelicals, Reformers and Education in Nineteenth Century Egypt. London: I.B. Tauris, 2011.

Shami, S. "The Circassians of Amman. Historical Narratives, Urban Dwelling and the Construction of Identity." In Amman: Ville Et Societé, edited by J. Hannoyer and S. Shami. Beirut: CERMOC, 1996.

Sharkey, H. J. Cultural Conversions: Unexpected Consequences of Christian Missions in the Middle East, Africa, and South Asia. Syracuse: Syracuse University Press, 2013.

Tadros Khalaf, N. Les Mémoires de 'Issa al-'Issa. Journaliste et intellectuel palestinien (1878-1950). Paris: Karthala, 2009.

Tamari, S. Mountain Against the Sea: Essays on Palestinian Society and Culture. Berkeley: University of California Press, 2008.

Tobelem, J.-M. L'arme de la culture - Les stratégies de la diplomatie culturelle non gouvernementale. Paris: L'Harmattan, 2007.

Tsimhoni, D. "The Greek Orthodox Patriarchate of Jerusalem During the Formative Years of the British Mandate in Palestine." Asian and African Studies 12, no. 1 (1978): 77-121.

- Christian Communities in Jerusalem and the West Bank Since 1948. London: Praeger, 1993.

Verdeil, C. La mission jésuite du Mont-Liban et de Syrie (1830-1864). Paris: Les Indes Savantes, 2011.

- Missions chrétiennes en terre d'islam (XVIIe-XXe siècles). Anthologie de textes missionnaires. Turnhout: Brepols, 2013.

Ware, T. The Orthodox Church. Harmondsworth: Penguin, 1963.

Wilson, M. C. King Abdullah, Britain and the Making of Jordan. Cambridge: Cambridge University Press, 1990.

- "The Hashemite, the Arab Revolt, and Arab Nationalism." In The Origins of Arab Nationalism, edited by K. Rashid, Lisa Anderson, Muhammad Muslih, and S. Reeva Simon, 204-224. New York: Columbia University Press, 1991.

Woroniecka-Krzyzanowska, D. "State, Sport and Resistance: A Case of Palestinian Sports Clubs in the West Bank." International Review for the Sociology of Sport, Online First (March 2019). 
Open Access This chapter is licensed under the terms of the Creative Commons Attribution 4.0 International License (http://creativecommons.org/licenses/ by $/ 4.0 /)$, which permits use, sharing, adaptation, distribution and reproduction in any medium or format, as long as you give appropriate credit to the original author(s) and the source, provide a link to the Creative Commons license and indicate if changes were made.

The images or other third party material in this chapter are included in the chapter's Creative Commons license, unless indicated otherwise in a credit line to the material. If material is not included in the chapter's Creative Commons license and your intended use is not permitted by statutory regulation or exceeds the permitted use, you will need to obtain permission directly from the copyright holder. 